\title{
THE QUESTION OF INTEGRATION OF THE SOUTHERN MEDITERRANEAN COUNTRIES COMPARED TO THE GLOBALIZATION DYNAMICS
}

\author{
Faradji Mohamed Akli \\ Sociology research professor Faculty of Social sciences and humanities \\ University of Bejaia. ALGERIA
}

\begin{abstract}
The subject of integration of the southern countries in the global space represents one of the major questions wish concerns the strategic choices and the development of countries in the southern area of the Mediterranean continent. However, the conditions for integration of this area are not yet fully met. This present research project proposes a sociological reading of the issue of integration of the north African States in the dynamics of globalization through their reports to the European and Mediterranean space.
\end{abstract}

In the other hand our interrogation is also the question related with the phenomena of peace and the question of development in this same space of economic and political integration.

Keywords: integration, partnership, cooperation, globalization.

\section{INTRODUCTION}

It is often said, especially by economists, that trade, finance and economic activities of enterprises are the living substance of a pan increasingly important in the development of external relations. It is in this atmosphere that international partnerships offer attractive opportunities to achieve common goals; however, the cooperation and joint ventures policies sometimes give unstable results and often disappointing.

Mediterranean region represents one of the richest areas of the globe, including the transformation of populations has led to profound changes in societies and economies of the area; there would be no local or national culture or firms or national product, but one thing will remain: it is the interest among peoples and nations that form the world of the future. It must follow the pattern all-exchange and cooperation between countries. The question we propose to study through this reflection is to examine the deeper meaning and the value of the integration process in the southern Mediterranean region in the movement of globalization. But in this context, the case of the Maghreb particular interest to us through its links with the countries of the European community that can be the starting point of its successful integration into the global space.

The Mediterranean is an area comprising twenty-two countries, on three continents (Europe, Africa and Asia). It is also a rich cultural and natural outcome of a sharing diverse heritage.

The issue of Europe-Maghreb partnership has always been of paramount concern to the northern shore companies and the southern shore of the Mediterranean. The vast majority of governments in the region demonstrate their willingness to increase the links of economic cooperation and also reflect a choice to undertake structural, legal and institutional reforms necessary for the implementation of a project a market 
economy, capable of sustainable economic growth.

In this perspective of strategic choices those countries of the European community and the countries of the southern Mediterranean must approve their rules of external relations.

Today the Mediterranean region is facing new series of economic globalization and regionalization challenges due to the rapid change of forms of organization savings during the last years.

\section{THE CONDITIONS OF INTEGRATION IN THE MEDITERRANEAN SPACE:}

\subsection{For the North Countries}

The creation of a free trade area between the EEC and the central Maghreb countries is one of the strategic choices of a Mediterranean development policy. But the translation of this policy must be accompanied by a number of conditions for this integration project:

\subsubsection{The consolidation of regional links}

Thinking the Mediterranean from both sides of its banks, also means acting in the prospects of regional, social and economic development. In this option, we can talk about several ways for strengthening regional relations between the northern and southern countries. The launch of the Euro-Mediterranean partnership policy is one of the most effective approaches to strengthen political and economic relations engaged in the region. Since the Barcelona Conference (Nov1995), the countries of the northern shore have not committed an effective action to integrate the Mediterranean riparian countries that are in the south west of the arc.

Some financial institutions as B.E.I still remain insufficient given the emergence of economic and social needs of the southern region.

Most of these funding projects mainly concern the energy sector, including the establishment of trans pipelines to meet the energy needs of the European community.

The issue of Europe-Maghreb partnership has always been of paramount concern to the northern shore companies and the southern shore of the Mediterranean. The vast majority of governments in the region demonstrate their willingness to increase the links of economic cooperation and also reflect a choice to undertake structural, legal and institutional reforms necessary for the implementation of a project as a market economy, sustainable for economic growth.

It will be possible also to create a favorable economy for the suitable climate of social and economic development, and thus for the peace and stability of the peoples of the region.

It is in this perspective of strategic choices that countries of the European community and the countries of the southern Mediterranean must approve their rules of external relations.

\subsubsection{Aid to finance partnership projects}

Despite the new European Union strategy is also another voice to develop economic relations between countries of the two Mediterranean shores, the level of funding is not yet able to meet the needs of social development and aspirations of the region

Many countries of the South Mediterranean are confronted today with economic reform and structural problems. In this context of economic reforms, the countries of this region will present more attractive to foreign investors, but the magnitude of welfare gains will depend on the extent to which these countries implement economic and trade reforms. However, the conditions for success of these reforms can be at the heart of the Mediterranean Strategy for development, so that these choices result in maximum benefits for all Mediterranean countries.

To encourage economic and social development of countries in the region, the European Investment Bank should strengthen its cooperation with financial operators of the Maghreb countries. So these countries will support the process of economic reform and the achievement of macroeconomic stability to create a zone of free trade between the European Union and the countries of the south shore of the Mediterranean.

\subsubsection{The consolidation of peace and political stability of countries in the southern Mediterranean Arc}

Provide the necessary justifications for the management of a mutually beneficial partnership process also involves research and analysis resources to mitigate "prior conflicts" between players in this geopolitical area Euro-Maghreb. 
The strengthening of peace and stability in the region requires a strategic and effective management to identify the socioeconomic characteristics likely to trade relations in the Euro- Maghreb area. Although the global economy in recent years is based on the opening of new areas, markets in regional assemblies tend to build as part of a voluntary accession process of the various partners.

The proliferation of trade agreements is the first fruits of this voluntary membership. But the issue of security appears to be an important dimension in the accession process intra - regional Euro-Maghreb to the view of the events in Central Maghreb during the last decade. As long as it is not definitively settled the question of the security does not play "thoroughly" the law of comparative advantage.

This is why the dynamics of free trade between the two shores of the Mediterranean still remains in an embryonic state. It is therefore necessary that cooperation in this area is accompanied by the first definition of a common strategy related to management of the problems of security, as is true that the stability of all countries in this area is necessary.

\section{FOR THE SOUTHERN COUNTRIES}

the southern countries must also make a set of conditions and reforms in suitable political choices in order to realize the political and economic integration in the Mediterranean zone, we can explain this solution by deferent strategic choices;

\subsection{By the Political and Economic Openness to The North}

The Euro-Maghreb regional assembly can be achieved through an adaptation of the foreign policy of countries in the European community and will have to open more towards the countries of the southern Mediterranean arc, especially to the Maghreb. On the other hand, with the current opening of the Maghreb countries to the global market economy. This integration process will be mutually beneficial to the all peoples of the region.

The debate already underway on the political and sociological conditions of open space "Maghreb", will decide on the issue of strategic choices to determine the most effective way for the development of the whole region. this not only the fruit of a new orientation of external relations, but rather the result of a common history, values, already dating since the Numidian era and Carthage city. This is why it will be necessary important to develop the strategic decision imposing the need for cooperation in the EuroMaghreb today.

The retrospective reading of the common history reflects the need to give back to the Mediterranean cooperation as a new impetus in favor of economic globalization which is imposed on all at the dawn of the 3rd millennium. But the cooperation of the countries of the Mediterranean region does not arise only in terms of political choices, but also in political suitable for future of the Mediterranean countries.

\subsection{A Flexibility of Economic Regulation and Organizational Structures}

Today, globalization is a phenomenon that by definition beyond the limited framework of the nation state. It is an imperative given that applies to all countries.

Therefore, it involves a challenge, sometimes radical structures and old models of organizations of Economic Affairs.

It is also clear that these mutations many argue for a permanent adaptation of the structures put in place in the organization scheme and the role of the state in a global dimension.

This transformation of organizational and spatial dimensions became today as a new track of negotiations to lead the peoples of different countries to delineate new interdependent relationships. It is in this sense that the negotiations on the political and economic integration of the countries of the southern shore can be done.

The need for such integration is conditioned by effective management of common interests and objectives of the Euro-Mediterranean area

\subsection{The Achievement of Macroeconomic Stability}

To promote exchanges the countries of southern Mediterranean must adopt an exchange rate policy to attract foreign capital. In addition, these countries are more macroeconomic imbalances more they will have difficulties to attract foreign investment. This is why economic transition in this context, will reveal themselves effective if it is accompanied with the necessary organizational adaptations. Then it is necessary to change the tax structure to establish a tax base hitting all areas of internal operations to offset declines in revenue generated by a voluntary trade in a free trade zone. 
The real question therefore is: what type of change to be made to preserve this space? and what are the organizational and legal mechanisms for the formation of an area of political and economic integration in this region of the world?

\subsection{The Creation of The New Mediterranean Development Policy}

The experience of emerging countries shows, as a priority, that the prospect of cooperation is one of the vectors of both the technical progress and economic development. In this context, the European and Maghreb countries must develop a new Mediterranean solution. In this all actors of the same space must also project to find new solutions of economic and social problems. This is a new integration based on a new Mediterranean cooperation. In this perspective, it will be possible to win together all geostrategic battles of the future and for a long time of this region.

\section{CONCLUSION}

The Euro-Maghreb partnership project would, as we have seen, a framework for dialogue and exchange necessary for the economic and political future of the peoples of the region.

Thus, one can point out that the creation of an area of the Mediterranean cooperation has become in recent years one of the main directions of the choice of economic policies of countries on both sides.

But the existence of such a conventional environment is conditioned by a set of necessary organizational conditions so that the Mediterranean can hope one day to an effective economic and social integration. Although the Euro-Mediterranean partnership strategy is clearly displayed in favor of such a space, but the question is always posed in terms of mechanisms and specific measures to develop strategic cooperation of the countries of the region.

Today in the era of a world increasingly globalized, it is urgent to affirm the theory of hegemonic stability, that the stability of the international system is conditioned by the production of international and common goods.

\section{REFERENCE LIST}

Abdelkader Sid Ahmed,1995. un projet pour l'Algérie: Eléments pour un réel partenariat euroméditerranéenne, publisud.

David G Mayes, 1994. Social Science, the evolution of rules for a single européan market, European Commission, proceding frome the Coste A 7 work shop in Exeter, Uk 8 to 11 September.

Kader, Bichar, 1992. Le grand Maghreb et l'Europe, Paris, publisud, quorum, cemac,

Lums daine D.H, moral vision in international politics, the forreign Aid Régime (1949-1989), Princeton University Press, 1993.

Schlie, ulrich, 1992 « the méditerranean challenge: Europe and north Africa, n 1,2 Stuttgart .

Wendt A,1994. "Collective Identity Formation and the international state" Americain political science review, $(p ; 385)$.

\section{- Documents divers:}

European Commision, 1988. the Europe- south dialogue, Brussels.

l'Europe des quinze, chiffres clés, édition 2000,communauté européenne ,2000.

Traité d'Amesterdam, 1999. ce qui a changé en Europe, communautés européennes. 